\title{
Monoclonal Antibody KIF20B(10C7), MPP1
}

\section{Antigen Used for Immunization}

Antigen sequence, corresponding to amino acid 1772-1787 of human KIF20B, NP_001271188, uniport ID: Q96Q89.

\section{Method of Immunization}

Immunized female BALA/c mice with peptide-KLH and then harvested and pooled lymphocytes from all immunized mice.

\section{Parental Cell Line Used for Fusion}

Murine SP2/0 myeloma cells.

\section{Selection and Cloning Procedure}

1. Fused cells plated onto selective medium and transferred clones to 96-well plate.

2. Primary screening performed by indirect enzyme linked immunosorbent assay on screening antigen (peptideBSA), probing with secondary antibody for both $\operatorname{IgG}$ and IgM.

3. Secondary testing by indirect immunofluorescence (IIF), Western blotting, and addressable laser bead immunoassay (ALBIA). ${ }^{(1-3)}$

\section{Heavy and Light Chains of Immunoglobulin}

IgG1.

\section{Specificity}

Epitope mapping (overlapping 15mer peptides), IIF, Western blot, ALBIA.

\section{Specific Antigen Identified}

KIF20B peptide (QPKRAKRKLYTSEISS).

\section{Availability}

\begin{tabular}{lll}
\hline & Yes & No \\
\hline Tissue culture supernatant & {$[\mathrm{X}]$} & {[]} \\
Ascitic fluid & {[]} & {$[\mathrm{X}]$} \\
Hybridoma cells & {$[\mathrm{X}]$} & {[]} \\
\hline
\end{tabular}

\section{References}

1. Fritzler MJ, Kerfoot SM, Feasby TE, Zochodne DW, Westendorf JM, Dalmau JO, and Chan EKL: Autoantibodies from patients with idiopathic ataxia bind to M-phase phosphoprotein 1 (MPP-1). J Invest Med 2000;48:28-39.

2. Zochodne DW, Auer R, and Fritzler MJ: Longstanding ataxic demyelinating polyneuropathy with a novel autoantibody. Neurology 2003;60:127-129.

3. Fritzler MJ, Brown RD, and Zhang M: A monoclonal antibody to M-phase phosphoprotein 1/kinesin-like protein KIF20B. Monoclon Antib Immunodiagn Immunother 2019;38:162-170.

Address correspondence to:

Marvin J. Fritzler

Department of Medicine

University of Calgary

3330 Hospital Drive NW

Calgary T2N4N1

Canada

E-mail: fritzler@ucalgary.ca

(C) Marvin J. Fritzler et al. 2019; Published by Mary Ann Liebert, Inc. This Open Access article is distributed under the terms of the Creative Commons License (http://creativecommons.org/licenses/by/4.0), which permits unrestricted use, distribution, and reproduction in any medium, provided the original work is properly cited. 